University of South Carolina

Scholar Commons

\title{
Influence of Cardiorespiratory Fitness on the Association between C-Reactive Protein and Metabolic Syndrome Prevalence in Racially Diverse Women
}

\author{
MICHAEL J. LAMONTE
}

BARBARA E. AINSWORTH

J. Larry Durstine

University of South Carolina - Columbia, Idurstin@mailbox.sc.edu

Follow this and additional works at: https://scholarcommons.sc.edu/

sph_physical_activity_public_health_facpub

Part of the Public Health Commons

\section{Publication Info}

Published in JOURNAL OF WOMEN'S HEALTH, Volume 14, Issue 3, 2005, pages 233-239.

LaMonte M.J.,Ainsworth, B.E. and Durstine, J.L.(2005). Influence of cardiorespiratory fitness on the association between $\mathrm{C}$-Reactive Protein and the metabolic syndrome prevalence in racially diverse women. Journal Women's Health, 14(3). 233-239.

This is a copy of an article published in the Journal of Women's Health (c) 2005 copyright Mary Ann Liebert, Inc.; Journal of Women's Health is available online at: http://online.liebertpub.com.

This Article is brought to you by the Physical Activity and Public Health at Scholar Commons. It has been accepted for inclusion in Faculty Publications by an authorized administrator of Scholar Commons. For more information, please contact digres@mailbox.sc.edu. 


\title{
Influence of Cardiorespiratory Fitness on the Association between C-Reactive Protein and Metabolic Syndrome Prevalence in Racially Diverse Women
}

\author{
MICHAEL J. LAMONTE, Ph.D., M.P.H., ${ }^{1}$ BARBARA E. AINSWORTH, Ph.D., M.P.H., ${ }^{2}$ \\ and J. LARRY DURSTINE, Ph.D. ${ }^{3}$
}

\begin{abstract}
Background: Metabolic syndrome and C-reactive protein (CRP) are independent predictors of cardiovascular disease (CVD) among women. The extent to which cardiorespiratory fitness influences the relationship between CRP and metabolic syndrome is unknown.

Methods and Results: Cross-sectional associations among fitness, CRP, and metabolic syndrome were examined in 135 African American, Native American, and Caucasian women (55 \pm 11 years, $28 \pm 6 \mathrm{~kg} / \mathrm{m}^{2}$ ). Fitness was quantified with a symptom-limited maximal treadmill exercise test. Plasma CRP concentrations were determined with the Dade-Behring high-sensitivity immunoassay. Metabolic syndrome was defined according to NCEP-ATP III. Metabolic syndrome, CRP, and fitness varied $(p<0.05)$ by race. Race-adjusted CRP values were directly associated $(p<0.05)$ with each metabolic syndrome component. After adjusting for age and race, the relative odds of metabolic syndrome was $3.6(95 \% \mathrm{CI}=1.5-8.4)$ in women with elevated $(>2.0 \mathrm{mg} / \mathrm{L})$ vs. low CRP. Adjustment for smoking, hormone therapy, body mass index (BMI), and HOMA insulin resistance did not eliminate this association $(p<0.05)$. The association between CRP and the metabolic syndrome was no longer significant $(\mathrm{OR}=1.3,95 \%$ $\mathrm{CI}=0.9-5.9, p=0.59)$ after adjustment for fitness.

Conclusions: Higher cardiorespiratory fitness may be an important consideration in the milieu of vascular inflammation and metabolic syndrome.
\end{abstract}

\section{INTRODUCTION}
A CCUMUlating EVIDENCE INDiCATES that C-re- active protein (CRP), a marker of subclinical inflammation, independently predicts the risk of cardiovascular disease (CVD) ${ }^{1}$ and diabetes ${ }^{2}$ among women. A strong relationship has also been shown for CRP with the prevalence ${ }^{3}$ and de- velopment ${ }^{4}$ of the metabolic syndrome in wo-

men. The metabolic syndrome characterizes coexisting high-risk phenotypes of hypertension, dyslipidemia, insulin resistance, and central obesity $^{5}$ that multiplicatively increase the risk of CVD $^{6}$ and diabetes. ${ }^{7}$ Two recent studies showed that the combination of elevated CRP and metabolic syndrome synergistically increased the risk of cardiovascular events and diabetes beyond that of either variable alone. 8,9 Chronic inflam-

\footnotetext{
${ }^{1}$ The Cooper Institute, Dallas, Texas.

${ }^{2}$ Department of Exercise and Nutritional Sciences, San Diego State University, San Diego, California.

${ }^{3}$ Department of Exercise Science, Arnold School of Public Health, University of South Carolina, Columbia, South Carolina.

This work was supported by NIH WHI-SIP 22W-U48/CCU409664 (B.E.A.)
} 
mation and the loss of metabolic homeostasis, as indicated by the metabolic syndrome, are potent cardiovascular antecedents and, when coexisting, identify an individual at high risk for a future event. Effective management of elevated CRP and metabolic syndrome may, therefore, have significant implications for the clinical and public health burden of CVD.

Physical activity is associated with lower cardiovascular and diabetes risk and improved risk factor profiles for both conditions. ${ }^{10}$ Studies have shown that physical activity is inversely related to $\mathrm{CRP}^{11,12}$ and to metabolic syndrome. ${ }^{13,14} \mathrm{We}$ reported $^{15}$ an inverse association between cardiorespiratory fitness, an objective measure of recent physical activity patterns, ${ }_{1}^{16}$ and $C R P,{ }^{11}$ as well as metabolic syndrome, ${ }^{13}$ in a cohort of racially diverse, healthy, middle-aged women in the Cross-Cultural Activity Participation Study (CAPS). To our knowledge, the influence of activity or fitness on the association between CRP and metabolic syndrome has not yet been examined. In the current study, we report cross-sectional associations among fitness, CRP, and metabolic syndrome in a racially diverse sample of women.

\section{MATERIALS AND METHODS}

Subjects were 44 African American, 45 Native American, and 46 Caucasian women who volunteered to participate in CAPS. The primary aim of CAPS was to develop physical activity surveys for diverse populations of women. ${ }^{11,13,15-17}$ CAPS inclusion criteria were self-reported African American, Native American, or Caucasian ethnicity, absence of symptomatic disease, and absence of conditions that would preclude daily physical activity. ${ }^{15}$ Interview-based health histories, body mass index (BMI, $\left.\mathrm{kg} / \mathrm{m}^{2}\right)$, waist girth $(\mathrm{cm})$, and resting blood pressure (BP) measures have been described. ${ }^{11,13,15-17}$

Following a 12-hour fast and 24-hour abstinence from exercise and smoking, antecubital blood was collected in EDTA, centrifuged, and frozen at $-80^{\circ} \mathrm{C}$ until analysis. Plasma CRP concentrations were measured with the DadeBehring high-sensitivity immunoassay, ${ }^{11}$ and elevated CRP was defined as $>2.0 \mathrm{mg} / \mathrm{L}^{1}{ }^{1}$ We recognize that this CRP cut point is lower than that currently recommend to define high risk. ${ }^{18}$ In the present analysis, a CRP level of $>2.0 \mathrm{mg} / \mathrm{L}$ is not meant to imply high risk but rather to identify wo- men whose CRP is elevated above a level considered to be normal or low risk $(1.0 \mathrm{mg} / \mathrm{L}) .{ }^{1,18} \mathrm{~A}$ CRP value of $2.0 \mathrm{mg} / \mathrm{L}$ approximates the median CRP in our sample of women, and this definition of elevated CRP is used to maintain consistency with previously reported data from our study. ${ }^{11,17}$ Plasma triglyceride, high-density lipoprotein (HDL) cholesterol, glucose, and insulin concentrations were obtained with standard automated bioassay procedures described elsewhere. ${ }^{17}$ Insulin resistance was quantified using the homeostasis model assessment ${ }^{19}$ (HOMA-IR). The Framingham 10 -year probability ${ }^{16}$ was used as a surrogate of coronary risk and analyzed categorically at $>75$ th percentile, which equates to a 10year probability $>6.0 \%$ among the apparently healthy asymptomatic cohort of CAPS women.

Metabolic syndrome was defined according to National Cholesterol Education Program (NCEP)-ATP III criteria ${ }^{5}$ as $\geq 3$ of the following: abdominal obesity (waist girth $>88 \mathrm{~cm}$ ), low HDL $(<50 \mathrm{mg} / \mathrm{dl})$, high triglyceride $(\geq 150$ $\mathrm{mg} / \mathrm{dl})$, high glucose $(\geq 110 \mathrm{mg} / \mathrm{dl})$, and high BP ( $\geq 130 / 85 \mathrm{~mm} \mathrm{Hg}$ ).

Fitness was quantified as the duration of a physician-supervised maximal treadmill exercise test consisting of 2-minute stages graded by 1 MET per stage ${ }^{11,16}$. Maximal exertion was seen as achieving $\geq 85 \%$ age-predicted maximal heart rate and perceived exertion $\geq 17$ on a 20 -point Borg scale. Fitness was standardized to age-adjusted maximal METs $\left(1 \mathrm{MET}=3.5 \mathrm{ml} \mathrm{O}_{2}\right.$ uptake $\cdot \mathrm{kg}$ body mass $\left.{ }^{-1} \cdot \mathrm{min}^{-1}\right)$ based on the final treadmill speed and grade. ${ }^{11}$ Women who achieved $\geq 8.5$ METs during the treadmill test were considered to be fit, and women who achieved $<8.5$ METs were considered to be unfit. This MET value was used as a cut point because it approximates a level of fitness associated with significant cardiovascular risk reduction among women. ${ }^{20}$

Summary statistics (mean, SD, frequencies) were computed for variables in general accord with the assumptions of normal distribution. CRP, HOMA-IR, triglyceride, and glucose were skewed; therefore, these variables were $\log (\mathrm{Ln})$ transformed, and geometric means are reported descriptively. Differences in CRP concentrations according to risk factor levels, metabolic syndrome status, and fitness were examined with the general linear model. Differences in proportions were examined with chi-square analyses. Logistic regression was used to examine crude and covariate adjusted associations between CRP and 
Table 1. Characteristics of Study Participants

\begin{tabular}{|c|c|c|c|}
\hline & African Americans & Native Americans & Caucasian \\
\hline$n$ & 44 & 45 & 46 \\
\hline Age, years ${ }^{\mathrm{a}}$ & $56.6 \pm 10$ & $50.1 \pm 9^{*}$ & $54.3 \pm 10$ \\
\hline $\mathrm{BMI}, \mathrm{kg} / \mathrm{m}^{2 \mathrm{a}}$ & $30.9 \pm 6$ & $28.7 \pm 6$ & $25.2 \pm 5^{*, * *}$ \\
\hline Waist, $\mathrm{cm}^{\mathrm{a}}$ & $89.0 \pm 13$ & $88.9 \pm 12$ & $78.4 \pm 11^{*, * *}$ \\
\hline Systolic BP, mm Hga & $129.2 \pm 18$ & $118.2 \pm 13^{*}$ & $116.3 \pm 19^{*}$ \\
\hline Diastolic BP, $\mathrm{mm} \mathrm{Hg}^{\mathrm{a}}$ & $79.4 \pm 9$ & $76.7 \pm 9$ & $76.6 \pm 9$ \\
\hline Triglyceride, $\mathrm{mg} / \mathrm{dl}^{\mathrm{b}}$ & $81.7 \pm 0.06$ & $114.2 \pm 0.07^{*}$ & $99.2 \pm 0.07$ \\
\hline $\mathrm{HDL}, \mathrm{mg} / \mathrm{dl}^{\mathrm{a}}$ & $65.3 \pm 19$ & $50.9 \pm 14^{*}$ & $57.6 \pm 14^{* *}$ \\
\hline Glucose, $\mathrm{mg} / \mathrm{dl}^{\mathrm{b}}$ & $91.6 \pm 0.03$ & $91.2 \pm 0.04$ & $84.4 \pm 0.02$ \\
\hline Insulin, $\mathrm{pmol} / \mathrm{L}^{\mathrm{b}}$ & $66.4 \pm 0.09$ & $56.4 \pm 0.11$ & $36.8 \pm 0.09^{* * * *}$ \\
\hline HOMA-IR & $15.8 \pm 0.09$ & $13.7 \pm 0.13$ & $8.6 \pm 0.09^{*, * *}$ \\
\hline $\mathrm{CRP}, \mathrm{mg} / \mathrm{L}^{\mathrm{b}}$ & $4.3 \pm 0.3$ & $2.5 \pm 0.3^{*}$ & $2.3 \pm 1.3^{*}$ \\
\hline Framingham score, $\%{ }^{a}$ & $4.6 \pm 0.41$ & $4.3 \pm 0.50$ & $4.3 \pm 0.55$ \\
\hline Treadmill time, $\min ^{\mathrm{a}}$ & $11.0 \pm 2.7$ & $13.5 \pm 3^{*}$ & $15.7 \pm 3^{*, * *}$ \\
\hline Maximal METs ${ }^{\mathrm{a}}$ & $7.2 \pm 1$ & $9.1 \pm 2^{*}$ & $10.0 \pm 2^{*, * *}$ \\
\hline Current smoker, \% & 8.7 & 4.4 & 6.5 \\
\hline Hormone replacement, \% & 47.8 & $11.1^{*}$ & $47.8^{* *}$ \\
\hline Abdominal obesity, \% & 51 & 47 & $17^{*, * *}$ \\
\hline Low HDL, \% & 17 & $53^{*}$ & $29^{*}$ \\
\hline High triglyceride, \% & 4 & $27^{*}$ & $19^{*}$ \\
\hline High glucose, $\%$ & 15 & 20 & $1^{*, * *}$ \\
\hline High $\mathrm{BP}, \%$ & 70 & $38^{*}$ & $32^{*}$ \\
\hline
\end{tabular}

aMean \pm SD.

${ }^{\mathrm{b}}$ Geometric mean \pm SE.

${ }^{*} p<0.05$ with African American; ${ }^{* *} p<0.05$ with Native American.

metabolic syndrome. Women with a CRP $\leq 2.0$ $\mathrm{mg} / \mathrm{L}$ were the referent group. All multivariable analysis controlled for age and race. Additional adjustment for hormone replacement therapy (HRT), BMI, HOMA-IR, and cardiorespiratory fitness was performed by entering each of these variables into separate models that already included CRP, age, and race. There were 12 women who self-reported a history of diabetes. After excluding these women and repeating the analysis, our primary findings were unchanged. Therefore, results are reported for the entire study sample including the women with diabetes. $p$ values are two-sided, and $p<0.05$ was accepted as statistically significant.

\section{RESULTS}

Participants were middle-aged and overweight and had relatively low coronary heart disease (CHD) risk factors (Table 1). Among all women, the prevalence of metabolic syndrome, elevated CRP, combined elevated CRP and metabolic syndrome, and a $\geq 8.5$ MET level of fitness was $22.6 \%, 45.9 \%, 17.8 \%$, and $50.4 \%$, respectively. The prevalence of these phenotypes varied significantly by race (Table 2). Crude and race-adjusted geometric mean CRP values were significantly higher among women stratified on the presence of metabolic syndrome and each of its components, fasting insulin, HOMA-IR, and fitness

Table 2. Prevalence of Metabolic Syndrome, Elevated CRP, and Fitness by Race

\begin{tabular}{|c|c|c|c|c|c|c|}
\hline & \multicolumn{2}{|c|}{ African American } & \multicolumn{2}{|c|}{ Native American } & \multicolumn{2}{|c|}{ Caucasian } \\
\hline & $\mathrm{n}$ & $\%$ & $\mathrm{n}$ & $\%$ & $\mathrm{n}$ & $\%$ \\
\hline Metabolic syndrome & 13 & 29.5 & 13 & 28.8 & 5 & $8.9^{*, * *}$ \\
\hline \multicolumn{7}{|l|}{ Elevated CRP } \\
\hline$>2.0 \mathrm{mg} / \mathrm{L}$ & 31 & 70.5 & 20 & $44.4^{*}$ & 13 & $28.2^{*, * *}$ \\
\hline $\begin{array}{l}\text { Metabolic syndrome } \\
\text { and } \\
\text { elevated CRP }\end{array}$ & 10 & 22.7 & 11 & 24.4 & 2 & $4.3^{*, * *}$ \\
\hline Fitness $\geq 8.5$ METs & 8 & 18.2 & 24 & $53.3^{*}$ & 35 & $76.1^{* * * *}$ \\
\hline
\end{tabular}

${ }^{*} p<0.05$ with African American; ${ }^{* *} p<0.05$ with Native American. 
Table 3. CRPa (Mg/L) Concentrations According to Risk Factor Category

\begin{tabular}{lll}
\hline & Unadjusted & Race adjusted \\
& & \\
Waist, cm & & \\
$\quad \leq 88$ & $2.5 \pm 0.2$ & $2.4 \pm 0.3$ \\
$\quad>88$ & $4.2 \pm 0.3^{*}$ & $3.9 \pm 0.3^{*}$ \\
Blood pressure, mm Hg & & \\
$\quad<130 / 85$ & $2.2 \pm 0.2$ & $2.3 \pm 0.2$ \\
$\quad \geq 130 / 85$ & $4.8 \pm 0.3^{*}$ & $4.7 \pm 0.1^{*}$ \\
$\quad$ Triglyceride, mg/dl & & \\
$\quad<150$ & $2.9 \pm 0.2$ & $2.8 \pm 0.2$ \\
$\quad \geq 150$ & $3.9 \pm 0.5^{*}$ & $4.0 \pm 0.4^{*}$ \\
HDL, mg/dl & & \\
$\quad \geq 50$ & $2.8 \pm 0.2$ & $2.7 \pm 0.2$ \\
$\quad<50$ & $3.4 \pm 0.4$ & $3.3 \pm 0.2$ \\
Glucose, mg/dl & & \\
$\quad<110$ & $2.5 \pm 0.2$ & $2.7 \pm 0.2$ \\
$\quad \geq 110$ & $6.3 \pm 0.6^{*}$ & $4.9 \pm 0.5^{*}$ \\
Insulin, pmol/L & & \\
$\quad<44$ & $2.2 \pm 0.3$ & $2.5 \pm 0.3$ \\
$\quad \geq 44$ & $3.9 \pm 0.2^{*}$ & $3.5 \pm 0.2^{*}$ \\
HOMA-IR & & \\
$\quad<9.8$ & $2.0 \pm 0.3$ & $2.2 \pm 0.3$ \\
$\quad \geq 9.8$ & $4.3 \pm 0.3^{*}$ & $3.9 \pm 0.2^{*}$ \\
Metabolic syndrome & & \\
$\quad$ Absent & $2.6 \pm 0.2$ & $2.6 \pm 0.2$ \\
$\quad$ Present & $4.8 \pm 0.4^{*}$ & $4.2 \pm 0.4^{*}$ \\
Fitness & & \\
$\quad<8.5 \mathrm{METs}$ & $3.8 \pm 0.3$ & $3.4 \pm 0.3$ \\
$\quad \geq 8.5 \mathrm{METs}$ & $2.4 \pm 0.4^{*}$ & $2.5 \pm 0.2^{*}$ \\
\hline
\end{tabular}

aData are geometric mean \pm SE.

${ }^{*} p<0.05$.

${ }^{b}$ Cut point for HOMA-IR is based on a median split among women without diabetes or impaired fasting glucose.

(Table 3). The proportion of women with elevated CRP, metabolic syndrome, or both was higher $(p \leq 0.005)$ among unfit than fit women (Table 4). The proportion of women with elevated CRP was higher in HRT users than nonusers $(59.2 \%$ vs. $34.1 \%, p<0.01)$ but was not associated with smoking status. Metabolic syndrome prevalence was not associated with smoking or HRT status. Figure 1 shows a direct association $(p<0.0001)$ between CRP concentration and the number of metabolic syndrome components present. Elevated CRP was strongly associated with metabolic syndrome prevalence in unadjusted $(\mathrm{OR}=$ $3.61, p=0.003)$ and in age-adjusted and race-adjusted (OR $=3.24, p=0.009)$ logistic regression models (Table 5). Additional adjustments for HRT, BMI, and HOMA-IR did not eliminate the association between CRP and metabolic syndrome $(p<0.02)$. However, adjustment for maximal MET levels of fitness eliminated the association between CRP and metabolic syndrome
$(\mathrm{OR}=1.39, p=0.59)$. In this model, fitness was inversely associated with metabolic syndrome $(\mathrm{OR}=0.89,95 \% \mathrm{CI}=0.76$ to $0.98, p=0.001)$ even with adjustment for age, race, and CRP.

To examine the implications of our findings on cardiovascular risk, we used a Framingham 10year probability above the 75th percentile $(>6 \%$ probability of developing (HD) as a surrogate end point. After adjusting for age and race, women with both high CRP and metabolic syndrome had an increased likelihood (OR $=8.16$, $95 \% \mathrm{CI}=1.61-12.14)$ of an elevated Framingham score compared with women who had neither risk factor. This association was eliminated when maximal METs was entered in the regression model $(\mathrm{OR}=2.9,95 \% \mathrm{CI}=0.91-5.97, p=0.20)$.

\section{DISCUSSION}

Two primary findings resulted from this crosssectional study. First, a significant direct association between elevated CRP and metabolic syndrome prevalence was observed in the racially diverse cohort of CAPS women, similar to that reported in predominantly white groups of U.S. women. ${ }^{3,8}$ Second, we extend existing literature by showing that the association between CRP and metabolic syndrome is eliminated once cardiorespiratory fitness is taken into account. Given that increasing physical activity is a front-line element of the national preventive and therapeutic algorithm for metabolic syndrome, ${ }^{5}$ these findings may have important clinical and public health implications.

The prevalence of metabolic syndrome $(25 \%)$, elevated CRP $(46 \%)$, and metabolic syndrome combined with elevated CRP (18\%) among CAPS women was generally consistent with the preva-

Table 4. Proportion of Women with Elevated CRP and Metabolic Syndrome by Fitness

\begin{tabular}{|c|c|c|c|c|c|}
\hline & \multicolumn{4}{|c|}{ Fitness } & \multirow[b]{3}{*}{$p$} \\
\hline & \multicolumn{2}{|c|}{$\begin{array}{c}<8.5 \\
M E T s\end{array}$} & \multicolumn{2}{|c|}{$\begin{array}{c}\geq 8.5 \\
\text { METs }\end{array}$} & \\
\hline & $\mathrm{n}$ & $\%$ & $\mathrm{n}$ & $\%$ & \\
\hline $\mathrm{CRP}>2.0 \mathrm{mg} / \mathrm{L}$ & 42 & 62 & 22 & 31 & 0.0005 \\
\hline Metabolic syndrome & 24 & 35 & 7 & 10 & 0.0004 \\
\hline $\begin{array}{l}\text { Elevated CRP and } \\
\text { metabolic syndrome }\end{array}$ & 17 & 25 & 5 & 7 & 0.005 \\
\hline
\end{tabular}




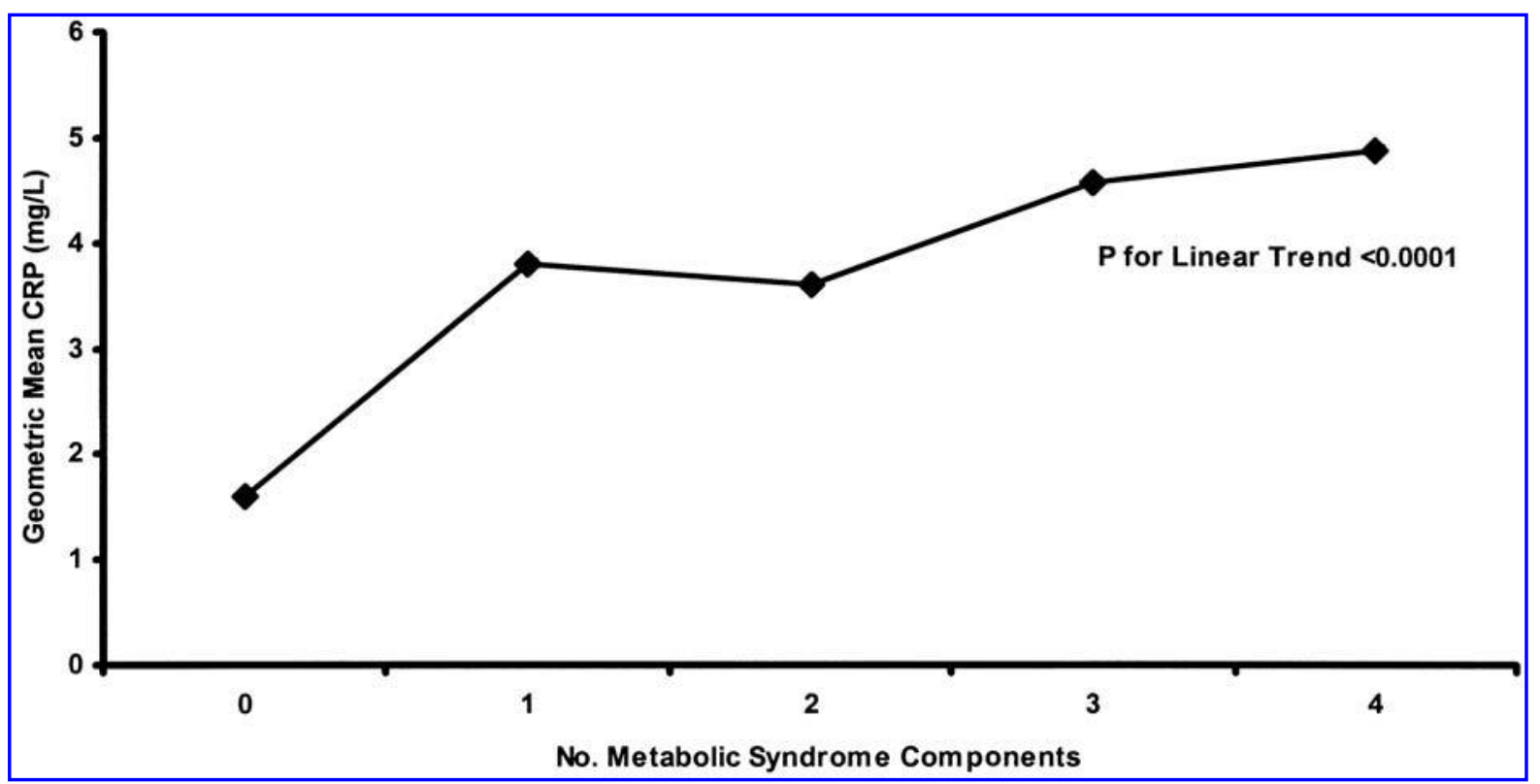

FIG. 1. Race-adjusted geometric mean CRP concentrations (mg/L) according to the number of metabolic syndrome components present in the study sample $(n=52,25,27,22$, and 9 , respectively).

lence of these phenotypes $(24 \%, 29 \%$, and $14 \%$, respectively) reported by Ridker et al. ${ }^{8}$ (computed from Figure 2, p.394) in a large cohort of healthy, predominantly white women of similar age (54 years) and BMI $\left(27 \mathrm{~kg} / \mathrm{m}^{2}\right)$ to CAPS women. Although there were differences in the prevalence of elevated CRP owing to differences in case definition, the association of CRP with each metabolic syndrome component and the number of coexisting factors was also very similar between CAPS women and the women reported on by Ridker et al. ${ }^{8}$ Ridker et al. showed cardiovascular risk was significantly elevated among women with either metabolic syndrome $(R R=2.3)$ or $C R P>3.0 \mathrm{mg} / \mathrm{L}(\mathrm{RR}=1.5)$ over the risk in women without either factor; but the risk was 4-fold higher among women who had both high CRP and metabolic syndrome. ${ }^{8}$ Similar findings were reported recently for cardiovascular and diabetes outcomes in men. ${ }^{9}$ We did not have prospective cardiovascular or diabetes events in CAPS. Our observation that the combination of elevated CRP and metabolic syndrome is associated with an 8-fold increase in the relative odds of having above the 75th percentile Framingham score is consistent with the strong direct prospective associations for this phenotype with cardiovascular events reported among women ${ }^{8}$ and men. ${ }^{9}$ Collectively, available cross-sectional and prospective data underscore the importance of identifying asymptomatic individuals with lowgrade inflammation and metabolic syndrome for intensive primary prevention of CVD and diabetes.

Table 5. Association between CRP and Prevalent Metabolic Syndrome

\begin{tabular}{|c|c|c|c|}
\hline Variable in model & Odds ratio ${ }^{\mathrm{a}}$ & $95 \% \mathrm{CI}$ & $\mathrm{p}$ \\
\hline $\mathrm{CRP}>2.0 \mathrm{mg} / \mathrm{L}$ & 3.61 & $1.54-8.44$ & 0.003 \\
\hline+ age & 3.43 & $1.57-8.83$ & 0.003 \\
\hline+ age + race & 3.24 & $1.58-7.90$ & 0.009 \\
\hline$+\mathrm{HRT}^{\mathrm{b}}$ & 3.79 & $1.57-9.17$ & 0.003 \\
\hline$+\mathrm{BMI}^{\mathrm{b}}$ & 2.62 & $1.96-7.13$ & 0.02 \\
\hline + HOMA-IR ${ }^{\mathrm{b}}$ & 1.82 & $1.66-5.02$ & 0.02 \\
\hline + Maximal METs ${ }^{\mathrm{b}}$ & 1.39 & $0.96-5.91$ & 0.59 \\
\hline
\end{tabular}

a Odds ratios are for prevalent metabolic syndrome in women with CRP $>2.0 \mathrm{mg} / \mathrm{L}$ after adjusting for the specified covariable(s). Women with CRP $\leq 2.0 \mathrm{mg} / \mathrm{L}$ are the referent group.

${ }^{\mathrm{b}}$ Entered separately into a model with CRP, age, and race. 
National recommendations identify lifestyle modifications, including regular physical activity, as the cornerstone of preventing and treating metabolic syndrome. ${ }^{5}$ Accumulating evidence suggests higher levels of physical activity and fitness confer resistance to subclinical inflammation. ${ }^{11,12}$ Among CAPS women, maximal cardiorespiratory fitness, an objective marker of recent activity patterns, ${ }^{16}$ eliminated the association between elevated CRP and metabolic syndrome, as well as the association of combined elevated CRP and metabolic syndrome with an elevated Framingham score. The latter observation is consistent with prospective data showing higher fitness is related to lower cardiovascular mortality among women. ${ }^{20}$ Although cross-sectional in nature, we believe the data reported herein suggest that enhanced cardiorespiratory fitness should be a primary mechanism for preventing increases in health risk associated with vascular inflammation and risk factor clustering, such as metabolic syndrome. Prospective studies in diverse populations of men and women are needed to better understand the degree of penetrance that activity and fitness have in the causal pathway of vascular inflammation and metabolic syndrome with diabetes and CVD.

Several mechanisms have been described that might lower CRP, metabolic syndrome, and their associated adverse risks among active and fit individuals. ${ }^{10-14,17,20}$ Potential mechanisms include enhanced natural killer (NK) cell activity against acute vascular infection, improved insulin sensitivity and glycemic control, and lower levels of body fat, circulating catecholamines, and oxidized low-density lipoprotein (LDL) cholesterol. Experimental data are needed to elucidate the specific etiological pathways through which an active and fit lifestyle mediates the long-term risk associated with elevated CRP and metabolic syndrome.

The current study has limitations that should be considered when interpreting and generalizing the findings reported herein. This study was an analysis of data collected during a larger investigation aimed at developing a culturally sensitive physical activity survey rather than examining the complex associations among fitness, CRP, and metabolic syndrome. Consequently, the relatively small sample and cross-sectional design restrict the power of statistical analyses and limit the conclusions and generalizations that can be drawn. Several of the effect estimates were bound by wide confidence intervals, likely owing to the small sample size and large variance within the data. We believe our analysis is, however, important because it is the first study to consider the influence of fitness on the high-risk phenotype of metabolic syndrome combined with elevated $\mathrm{CRP}$ in a racially diverse sample of asymptomatic women. We recognize that a modest genetic transmission contributes to individual levels of cardiorespiratory fitness. ${ }^{21}$ However, reported exercise training gains of up to $30 \%$ and rapid detraining-related losses ${ }^{22}$ illustrate the plasticity of cardiorespiratory fitness and should temper genetic arguments against targeting fitness enhancement as a part of disease prevention. We would hope that our cross-sectional data stimulate the design of large prospective analyses to provide more definitive data on the influence of fitness on elevated CRP and metabolic syndrome.

We conclude that elevated CRP is strongly associated with prevalent metabolic syndrome among racially diverse women. Higher levels of cardiorespiratory fitness appear to favorably influence the association between CRP and metabolic syndrome. This observation may be a mechanism of cardioprotection associated with an active and fit lifestyle and is further support for current recommendations promoting physical activity and fitness in the primary prevention of cardiovascular and related diseases.

\section{ACKNOWLEDGMENT}

We thank our coinvestigators, administrative staff, and participants for their contribution to CAPS.

\section{REFERENCES}

1. Ridker PM. High-sensitivity C-reactive protein. Potential adjunct for global risk assessment in the primary prevention of cardiovascular disease. Circulation 2001;103:1813.

2. Pradhan AD, Manson JE, Rifai N, Buring JE, Ridker PM. C-reactive protein, interleukin 6, and risk of developing type 2 diabetes mellitus. JAMA 2001;286:327.

3. Ford ES. The metabolic syndrome and C-reactive protein, fibrinogen, and leukocyte count: Findings from the Third National Health and Nutrition Examination Study. Atherosclerosis 2003;168:351.

4. Han TS, Satter N, Williams K, Gonzalez-Villalpando C, Lean MEJ, Haffner SM. Prospective study of C-re- 
active protein in relation to development of diabetes and metabolic syndrome in the Mexico City Diabetes study. Diabetes Care 2002;25:2016.

5. Expert Panel on Detection, Evaluation, and Treatment of High Blood Cholesterol in Adults. Executive summary of the third report of the National Cholesterol Education Program (NCEP) expert panel on detection, evaluation, and treatment of high blood cholesterol in adults. JAMA 2001;285:2486.

6. Lakka HM, Laaksonen DE, Lakka TA, et al. The metabolic syndrome and total and cardiovascular disease mortality in middle-aged men. IAMA 2002;288:2709.

7. Lorenzo C, Okoloise M, Willams K, Stern MP, Haffner SM. The metabolic syndrome as a predictor of type 2 diabetes. Diabetes Care 2003;26:3153.

8. Ridker PM, Buring JE, Cook NR, Rifai N. C-reactive protein, the metabolic syndrome, and risk of incident cardiovascular events. Circulation 2003;107:391.

9. Sattar N, Gaw A, Scherbakova O, et al. Metabolic syndrome with and without C-reactive protein as a predictor of coronary heart disease and diabetes in the West of Scotland Coronary Prevention Study. Circulation 2003;108:414.

10. U.S. Dept of Health and Human Services. Physical activity and health: A report of the Surgeon General. Atlanta, GA: Centers for Disease Control and Prevention, 1996.

11. LaMonte MJ, Durstine JL, Yanowitz FG, et al. Cardiorespiratory fitness and C-reactive protein among a tri-ethnic sample of women. Circulation 2002;106: 403.

12. Church TS, Barlow CE, Earnest CP, Kampert JB, Priest EL, Blair SN. Associations between cardiorespiratory fitness and C-reactive protein in men. Arterioscler Thromb Vasc Biol 2002;22:1869.

13. Irwin ML, Ainsworth BE, Mayer-Davis EJ, Addy CL, Pate RR, Durstine JL. Physical activity and the metabolic syndrome in a tri-ethnic sample of women. Obes Res 2002;10:1030.

14. Lakka T, Laaksonen DE, Lakka HM, et al. Sedentary lifestyle, poor cardiorespiratory fitness, and the metabolic syndrome. Med Sci Sports Exerc 2003;35:1279.
15. Ainsworth BE, Irwin ML, Addy CL, Whitt MC, Stolarczyk L. Moderate physical activity patterns of minority women: The Cross-Cultural Activity Participation Study. J Wom Health 1999;8:805.

16. LaMonte MJ, Durstine JL, Addy CL, Irwin ML, Ainsworth BE. Physical activity, physical fitness, and Framingham 10-year risk score: The Cross-Cultural Activity Participation Study. J Cardiopulm Rehab 2001;21:63.

17. LaMonte MJ, Ainsworth BE, DuBose KD, et al. The hypertriglyceridemic waist phenotype among women. Atherosclerosis 2003;171:123.

18. Pearson TA, Mensah GA, Alexander RW, et al. Markers of inflammation and cardiovascular disease. Application to clinical and public health practice. A statement for healthcare professionals form the Centers for Disease Control and Prevention and the American Heart Association. Circulation 2003;107:499.

19. Haffner SM, Gonzalez C, Miettinen H, Kennedy E, Stern MP. A prospective analysis of the HOMA model. Diabetes Care 1996;19:1138.

20. Blair SN, Kohl HW, Paffenbarger RS, Clark DG, Cooper KH, Gibbons LW. Physical fitness and allcause mortality. JAMA 1989;262:2395.

21. Bouchard C, Malina RM, Perusse L. Genetics of fitness and physical performance. Champaign, IL: Human Kinetics, 1997;119, 541.

22. Coyle EF. Deconditioning and retention of adaptations induced by endurance training. In: Roitman JL, Kelsey M, LaFontaine TP, eds. Resource manual for guidelines for exercise testing and prescription, 3rd ed. Philadelphia, PA: Lea \& Febiger, 1998:189.

Address reprint requests to: Michael J. LaMonte, Ph.D., M.P.H. The Cooper Institute 12330 Preston Road Dallas, TX 75230

E-mail: mlamonte@cooperinst.org 


\section{This article has been cited by:}

1. Maura Daly IversenIntroduction to Physical Medicine, Physical Therapy, and Rehabilitation 528-539. [CrossRef]

2. Stephen H. Boutcher, Sarah L. Dunn, E. Gail Trapp, Judith Freund. 2011. Regional adiposity distribution and insulin resistance in young Chinese and European Australian women. Scandinavian Journal of Clinical \& Laboratory Investigation 1-5. [CrossRef]

3. Tim Church. 2011. Exercise in Obesity, Metabolic Syndrome, and Diabetes. Progress in Cardiovascular Diseases 53:6, 412-418. [CrossRef]

4. Stacey A. Zeno , M.S., Patricia A. Deuster, Ph.D., M.P.H., Jennifer L. Davis , M.S., Su-Jong Kim-Dorner , Ph.D., Alan T. Remaley , M.D., Ph.D., Merrily Poth , M.D.. 2010. Diagnostic Criteria for Metabolic Syndrome: Caucasians Versus AfricanAmericans. Metabolic Syndrome and Related Disorders 8:2, 149-156. [Abstract] [Full Text HTML] [Full Text PDF] [Full Text PDF with Links]

5. Jiyoung Lee, Shin-Uk Kim, Hyun-Sik Kang. 2010. Low cardio/respiratory fitness as an independent predictor of metabolic syndrome in Korean young men. European Journal of Applied Physiology 108:4, 633-639. [CrossRef]

6. Jin-Kyung Cho, Tae-Kyung Han, Hyun-Sik Kang. 2010. Combined effects of body mass index and cardio/respiratory fitness on serum vaspin concentrations in Korean young men. European Journal of Applied Physiology 108:2, 347-353. [CrossRef]

7. Tongian You, Michael LaMonteRole of Exercise and Weight Loss in Reducing Inflammation 20091858, 255-284. [CrossRef]

8. Mary-Frances O’Connor, Julie E. Bower, Hyong Jin Cho, J. David Creswell, Stoyan Dimitrov, Mary E. Hamby, Michael A. Hoyt, Jennifer L. Martin, Theodore F. Robles, Erica K. Sloan, KaMala S. Thomas, Michael R. Irwin. 2009. To assess, to control, to exclude: Effects of biobehavioral factors on circulating inflammatory markers. Brain, Bebavior, and Immunity 23:7, 887-897. [CrossRef]

9. Zhigang Zhao, Hai Nie, Hongbo He, Zhencheng Yan, Daoyan Liu, Zhidan Luo, Liqun Ma, Yinxing Ni, Jin Chen, Jin Jing, Tingbing Cao, Hua Yang, Martin Tepel, Weiguo Zhang, Zhiming Zhu. 2007. High-sensitivity C-reactive protein predicts target organ damage in Chinese patients with metabolic syndrome. Metabolism 56:12, 1612-1619. [CrossRef]

10. Victoria J. Vieira, Rudy J. Valentine, Edward McAuley, Ellen Evans, Jeffrey A. Woods. 2007. Independent Relationship Between Heart Rate Recovery and C-Reactive Protein in Older Adults. Journal of the American Geriatrics Society 55:5, 747-751. [CrossRef]

11. Earl S Ford, Chaoyang Li. 2006. Physical activity or fitness and the metabolic syndrome. Expert Review of Cardiovascular Therapy 4:6, 897-915. [CrossRef] 